\title{
In Memoriam: Larry E. Davis
}

(c) Springer Science+Business Media, LLC, part of Springer Nature 2021

On March 30, 2021, Dr. Larry E. Davis, Dean Emeritus of the University of Pittsburgh's School of Social Work, passed away at the age of 74. A leading scholar of the discourse about race in America and its capacity to enable social justice, Dr. Davis was the founding director of Pitt's Center for Race and Social Problems and creator of its namesake journal Race and Social Problems, founded in 2009. After appointing Dr. Gary Koeske as Editor-in-Chief, Dr. Davis remained a guiding force behind the journal's special issues, invited papers and editorial voice. Dr. Davis was active with the journal until the end of his life, and his contributions to research and education on racial justice will endure for generations to come. It will continue to be the privilege of Springer to further Dr. Davis's mission as publisher of Race and Social Problems.

Please refer to the below obituary, provided by the University of Pittsburgh's Pittwire, for more details on the life and legacy of Dr. Larry Davis, and visit this page for even more remembrances: https://www.socialwork.pitt.edu/ remembrances-dean-emeritus-larry-davis

The University of Pittsburgh community is mourning the passing of Larry E. Davis, dean of Pitt's School of Social Work from 2001 to 2018 and founding director of its Center on Race and Social Problems. Davis died on March 30.

When Davis arrived at Pitt in 2001, he was already recognized as a leading scholar of the narrative about race in America and its role in social justice. In his extensively published research, he explored such concepts as "the psychological majority" and "the racial tipping point," which are critical to anticipating, understanding, and constructively managing the impact of race on the dynamics of group interaction in a wide range of settings, including neighborhoods, schools, and the workplace.

Under his leadership, the School of Social Work was ranked among the country's top 10 social work schools by the US News \& World Report. He recruited faculty members with wide-ranging specialties, made the school's doctoral program more rigorous, and gained a reputation for being the kind of leader who helped others be successful.

Davis created Pitt's Center for Race and Social Problems, the first such center to be created at any American school of social work. Its scholars conduct and disseminate applied social-science research on race, color, and ethnicity and mentor emerging scholars on race-related social problems. Through its programming, the center regularly exposes community leaders to the most current research relating to race.

One example is 2010's "Race in America" conference, which brought 1300 scholars, researchers, students, leaders of industry, public officials, community leaders, and others to Pitt's campus to grapple with the problems of race and inequality that exist in America today.

\section{References}

Mourning Larry E. Davis. (2020, March 31). Pittwire. https://www. pittwire.pitt.edu/news/mourning-larry-e-davis.

Publisher's Note Springer Nature remains neutral with regard to jurisdictional claims in published maps and institutional affiliations. 